\title{
Pelatihan Penulisan Penelitian Tindakan Kelas Berbasis Teknologi Open Journal System dan Penggunaan Software R pada MGMP Matematika SMP
}

\author{
Muhammad Taqwa ${ }^{1}$, Firdha Razak ${ }^{1}$, Amrullah Mahmud ${ }^{2}$ \\ ${ }^{1}$ Pendidikan Matematika, STKIP Andi Matappa, Jl. Andi Mauraga No. 70 Pangkajene, Kab. Pangkep, Indonesia, 90611 \\ ${ }^{2}$ Pendidikan Guru Sekolah Dasar, STKIP Andi Matappa, Jl. Andi Mauraga No. 70 Pangkajene, Kab. Pangkep, Indonesia, \\ 90611
}

*Email koresponden: muh.taqwa@stkip-andi-matappa.ac.id

\section{ARTICLE INFO \\ Article history}

Received: 11 Sep 2021

Accepted: 06 Nov 2021

Published: 31 Des 2021

Kata kunci:
MGMP Matematika;
OJS;
Pelatihan;
PTK;
Software R;

\section{Keyword:}

MGMP Mathematics;

OJS;

PTK;

Software R;

Training;

\begin{abstract}
A B S T R A K
Background: Guru Matematika yang tergabung dalam MGMP (Musyawarah Guru Mata Pelajaran) Matematika tingkat SMP Kabupaten Pangkep menghadapi permasalahan dalam penulisan penelitian tindakan kelas (PTK), mengolah dan menganalisis data hasil penelitian PTK menggunakan software, serta publikasi artikel ilmiah PTK di Open Journal System (OJS). Tujuan untuk meningkatkan (1) pengetahuan guru terhadap cara penulisan penelitian tindakan kelas (PTK); (2) pengetahuan guru tentang aplikasi statistika Software R; (3) pengetahuan guru tentang Open Journal System OJS). Metode: Model Pembelajaran Technology, Pedagogy, and Content Knowledge (TPACK) terdiri 4 langkah yaitu: pemahaman $(\mathrm{P})$, observasi-instruksi $(\mathrm{O})$, latihan instruksi (L), refleksi (R). Mitra Pelatihan adalah MGMP Matematika tingkat SMP Kabupaten Pangkep yang berjumlah 12 orang. Instrumen pengabdian berupa: tes pengetahuan penelitian tindakan kelas; tes pengetahuan software $R$; tes pengetahuan Open Journal System (OJS). Hasil: (1) meningkatnya pengetahuan guru terhadap cara penulisan penulisan tindakan kelas; (2) meningkatnya pengetahuan guru tentang mengolah data penelitian tindakan kelas dengan Software $R$; (3) Meningkatnya pengetahuan guru tentang publikasi artikel ilmiah penelitian tindakan kelas pada Open Journal System (OJS). Kesimpulan: Pelatihan PTK Berbasis Teknologi OJS Dan Penggunaan Software $R$ dapat mengatasi kesulitan guru dalam penulisan PTK, mengolah dan menganalisis data penelitian PTK, serta publikasi artikel ilmiah PTK di Open Journal System (OJS).
\end{abstract}

\section{A B S T R A C T}

Background: Mathematics Teachers who are members of MGMP (Teacher's Deliberation of Subjects) Mathematics at the Junior High School level of Pangkep Regency face problems in writing classroom action research (PTK), processing and analyzing data from PTK research results using software, as well as the publication of PTK scientific articles in the Open Journal System (OJS). The purpose of improving (1) the teacher's knowledge of the way of writing classroom action research (PTK); (2) the teacher's knowledge of software R statistical applications; (3) teacher knowledge of the Open Journal System (OJS). Method: Learning Model Technology, Pedagogy, and Content Knowledge (TPACK) consist of 4 steps: understanding (P), observationinstruction (O), instruction exercises (L), reflection (R). Training Partner is MGMP Mathematics junior high school pangkep which amounted to 12 people. Instruments of devotion in the form of tests of classroom action research knowledge; test of software knowledge R; Open Journal System (OJS) knowledge test. Results: (1) increased teacher knowledge of how to write class actions; (2) increased teacher knowledge about processing classroom action research data with Software R; (3) Increased teacher knowledge about the publication of scientific articles of classroom action research in the Open Journal System (OJS). Conclusion: OJS Technology-Based PTK Training and The Use of Software R can overcome teacher difficulties in writing PTK, processing and analyzing PTK research data, and publishing PTK scientific articles in the Open Journal System (OJS). 
(C) 2021 by authors. Lisensi Jurnal Solma, UHAMKA, Jakarta. Artikel ini bersifat open access yang didistribusikan di bawah syarat dan ketentuan Creative Commons Attribution (CC-BY) license.

\section{PENDAHULUAN}

Kabupaten Pangkajene dan Kepulauan, juga dikenal sebagai Kabupaten Pangkep, adalah salah satu kabupaten di Provinsi Sulawesi Selatan, memiliki luas total 12.362,73 km2, termasuk 898,29 km2 darat dan 11.464,45 km2 laut. Ada 92 Sekolah Menengah Pertama (SMP) Sederajat di Kabupaten Pangkep yang terdiri dari 78 SMP Negeri dan 14 SMP Swasta, yang tersebar di 13 kecamatan dengan jumlah total peserta didik yaitu 14.841 siswa (Direktorat Jenderal Pendidikan Anak Usia Dini, 2021), sehingga rasio perbandingan jumlah sekolah dengan jumlah peserta didik di tingkatan SMP yaitu 1: 161. Kecamatan Pangkajene merupakan kecamatan tempat ibu kota Kabupaten Pangkep, Pangkajene, berada, memiliki distribusi peserta didik tingkatan SMP terbanyak. Kecamatan ini memiliki total 8 SMP, MTs, dan sederajat.

Di kabupaten inilah STKIP Andi Matappa berada, serta sekolah yang berfungsi sebagai mitra PKM untuk STKIP Andi Matappa. Ada 41 guru matematika di Kabupaten Pangkajene, menurut Musyawarah Guru Mata Pelajaran (MGMP) Matematika Tingkat SMP. Tim PKM mengetahui bahwa guru matematika di Kabupaten Pangkajene yang tergabung dalam MGMP Matematika tingkat SMP tidak pernah mengikuti pelatihan, lokakarya, atau acara serupa yang terkait dengan penulisan penelitian tindakan kelas menggunakan teknologi OJS dan perangkat lunak statistik $\mathrm{R}$ sehingga melalui pelatihan ini mereka bisa meningkatkan pengetahuan mengenai cara penulisan PTK dengan baik dan benar, mampu mengolah sendiri data hasil penelitian melalui statistik R dan mampu mempublikasikan sendiri laporan artikel PTK melalui teknologi OJS.

MGMP Matematika SMP Kabupaten Pangkep sekarang di ketua oleh Bapak Abdul Azis, S.Pd., M.Pd. yang merupakan guru di SMP Negeri 1 Pangkajene sekaligus sebagai sekertariat MGMP Matematika SMP. MGMP Matematika SMP Kabupaten Pangkep saat ini membina kurang lebih 300 guru yang tersebar di 13 Kecamatan. Jika dibandingkan jumlah guru matematika di Kecamatan Pangkajene dan jumlah peserta didik tingkatan SMP maka akan diperoleh rasio 41:2.546 atau setara 1:62 (Direktorat Jenderal Pendidikan Anak Usia Dini, 2021). Meskipun dimasa pandemi Covid-19, pertemuan reguler guru-guru matematika tetap dilaksanakan dengan memperhatikan protokol kesehatan yaitu pembatasan guru yang hadir setiap minggu. Kegiatan survei yang dilakukan terhadap 8 orang guru matematika dari SMP Negeri 1 Pangkajene dan SMP Negeri 2 Pangkajene memberi informasi bahwa kesulitan penulisan penelitian tindakan kelas (PTK), kesulitan publikasi artikel PTK secara online serta rendahnya kemampuan guru dalam penggunaan software untuk analisis data penelitian merupakan tiga masalah yang ditemukan.

Ketiga isu ini sebagian besar disebabkan oleh kemampuan guru yang tidak memadai dalam menulis penelitian tindakan kelas (PTK). Guru yang berkompeten akan dapat menulis penelitian tindakan kelas (PTK), menganalisis data dengan software, dan menerbitkan artikel penelitian class action (PTK) sebagai prasyarat kenaikan pangkat guru sesuai Permendiknas Nomor 16 Tahun 2007 mengenai Standar Kualifikasi Akademik dan Kompetensi Guru. Mereka tidak ingin skenario yang sama terjadi di Kabupaten Gowa pada tahun 2019, Operasi Tangkap Tangan (OTT) dua guru penyusun PTK bagi yang ingin naik pangkat. Pembuatan PTK tersebut lazim, khususnya di 
Kabupaten Pangkep. Sebagai konsekuensi dari pembicaraan antara tim PKM dan mitra, lebih lanjut dibenarkan bahwa masalah utama yang disetujui untuk ditangani selama pelaksanaan program PKM adalah bagaimana membuat penelitian tindakan kelas (PTK) dan bagaimana mengevaluasi data penelitian. Mereka berharap bahwa penelitian tindakan kelas (PTK) yang dihasilkan dapat dianalisis secara independen dan diterbitkan dalam OJS bersertifikat nasional, sehingga berbeda dari seminar/lokakarya/pelatihan yang telah mereka hadiri. Bagi mereka, selama ini seminar/workshop/pelatihan baru saja menjadi kuliah dan telah berakhir tanpa ada makalah yang diterbitkan dalam jurnal, oleh karena itu mereka tidak dapat memanfaatkannya untuk file kenaikan pangkat. Akibatnya, pelatihan diperlukan untuk menyediakan guru dengan keterampilan yang dibutuhkan untuk melakukan penelitian dan menulis publikasi ilmiah. Contoh yang lebih spesifik harus diberikan dalam pelatihan, serta kesempatan bagi guru untuk mencoba belajar dan menulis dengan pendampingan (Pursitasari, 2014).

Tujuan kegiatan pelatihan ini: (1) untuk meningkatkan pengetahuan guru terhadap cara penulisan PTK dengan baik dan benar; (2) untuk meningkatkan pengetahuan guru mengolah data penelitian PTK dengan Software R; (3) untuk meningkatkan pengetahuan guru tentang publikasi artikel ilmiah PTK di OJS.

\section{MASALAH}

Penelitian Tindakan Kelas merupakan kewajiban bagu guru profesional. Termasuk bagi guru di Mitra pengabdian masyarakat ini adalah MGMP Matematika Tingkat SMP Kab. Pangkep. Berbagai pelatihan telah diikuti oleh tim mitra, akan tetapi kegiatannya hanya berupa ceramah materi PTK saja. Padahal guru dari Mitra pengabdian menghadapi: (1) kesulitan penulisan penelitian tindakan kelas (PTK) belum dijadikan sebagai kebutuhan utama guru. Masih belum terbiasa menulis PTK dan hanya membuat PTK demi memenuhi syarat administratif kenaikan pangkat; (2) kesulitan mengolah dan menganalisis data hasil penelitian menggunakan software; serta (3) kesulitan publikasi artikel PTK di jurnal. Adanya perubahan manajemen jurnal dari jurnal cetak ke jurnal online dengan teknologi OJS menambah kompleksitas kesulitan guru dalam memenuhi syarat administratif kenaikan pangkat. Oleh karena itu, mitra mengharapkan agar pelatihan tidak hanya sebatas menyususn penelitian tindakan kelas (PTK), tetapi datahasil penelitian dapat dianalisis sendiri serta terciptanya artikel ilmiah yang terpublikasi di OJS yang terakreditasi secara nasional. Kebutuhan pokok dari mitra sesuai dengan tujuan kegiatan pengabdian pelatihan penulisan penelitian tindakan kelas berbasis teknologi open journal system dan penggunaan software $R$. R merupakan software statistika yang popular, lengkap, dan berlisensi gratis sehingga terhindar dari tuntutan hukum saat mengolah dan menganalisis data hasil penelitian serta memiliki visualisasi grafik yang lebih canggih dibandingkan software statistika lainnya. Olehnya itu, sebagai pendidik sekaligus abdi negara seharusnya menggunakan software pengolahan data yang berlisensi gratis tanpa harus membajak untuk menggunakan software hak cipta seseorang sehingga diharapkan menjadi contoh bagi teman sejawat atau orang lain tentang rasa menghormati hak cipta seseorang (Rosida et al., 2021). 


\section{METODE PELAKSANAAN}

Kegiatan PKM dilakukan tanggal 9 September 2021 di Laboratorium Microteaching STKIP Andi Matappa, Kelurahan Tumampua, Kec. Pangkajane, Kab. Pangkep. Kelompok sasaran kegiatan pengabdian masyarakat ini adalah MGMP Matematika Tingkat SMP Kab. Pangkep sebanyak 12 orang. Model Technology, Paedagogy, and Content Knowledge (TPACK) adalah metode pelaksanaan kegiatan yang dilakukan dalam pelatihan ini dengan tetap mematuhi protokol kesehatan. Model terdiri dari 4 langkah yaitu: pemahaman $(\mathrm{P})$, observasi-instruksi $(\mathrm{O})$, latihan instruksi (L), refleksi (R) (Nur \& Nasir, 2018, 2019).

Teknik pengumpulan data dengan menggunakan instrumen (1) tes pengetahuan penelitian tindakan kelas; (2) tes pengetahuan software R; (3) tes pengetahuan online journal system. Untuk melihat peningkatan pengetanuan maka masing-masing diberikan sebanyak dua kali yaitu pretes di awal pelatihan dan posttest, di akhir pelatihan. Data kemudian di dianalisis dengan teknik statistika deskriptif dengan software R (Taqwa, 2021; Taqwa \& Taufik, 2019b).

\section{HASIL DAN PEMBAHASAN}

\section{Pengetahuan Guru Terhadap cara Penulisan Penelitian Tindakan Kelas}

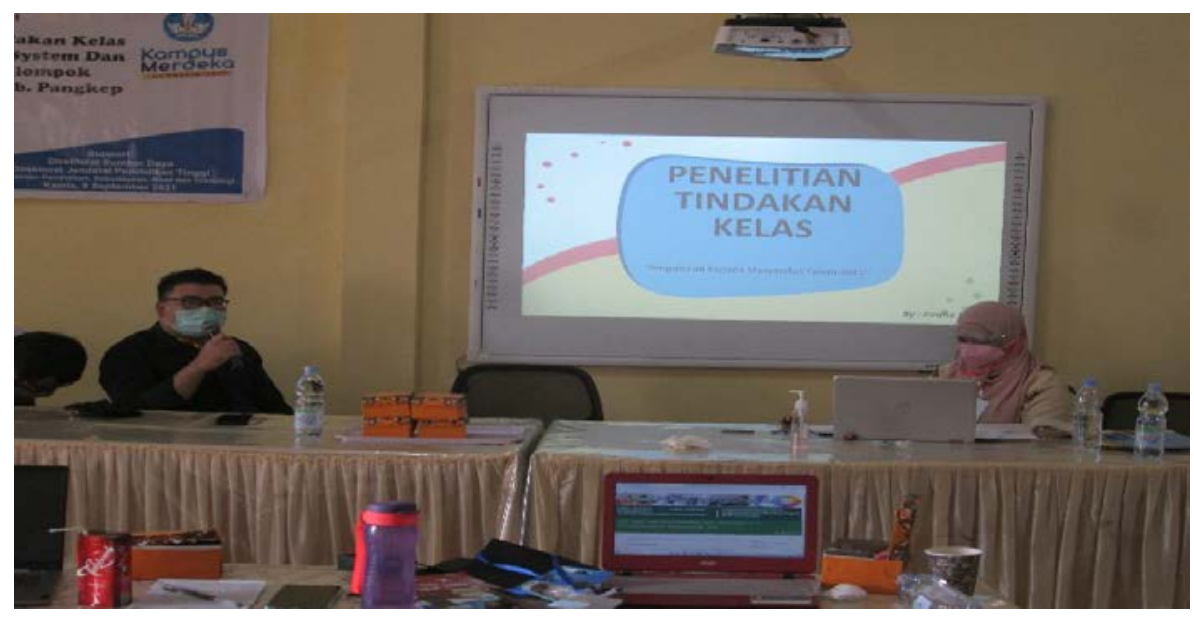

Gambar 1. Penyajian Materi PTK oleh Firdha Razak, S.Pd, M.Pd

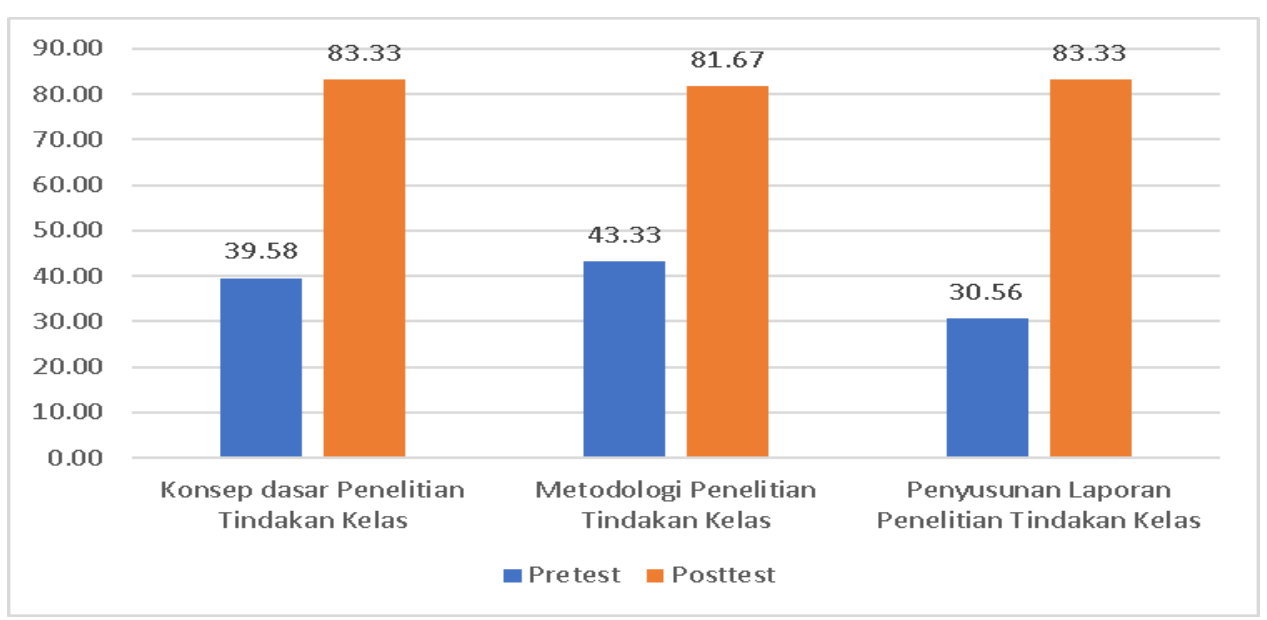

Gambar 2. Pengetahuan Guru Terhadap cara Penulisan Penelitian Tindakan Kelas 
Grafik Gambar 2. menggambarkan peningkatan pengetahuan guru tentang cara menyusun penelitian tindakan kelas pada indikator pengetahuan konsep dasar penelitian tindakan kelas, metodologi penelitian tindakan kelas, dan penyusunan laporan penelitian tindakan kelas. Setelah mengajar mitra tentang cara menyusun penelitian tindakan kelas masalah kesulitan penulisan penelitian Tindakan kelas (PTK) berhasil diatasi berkelompok/klasik maupun individual.

\section{Pengetahuan Guru Tentang Mengolah Data Penelitian Tindakan Kelas Dengan Software $R$}

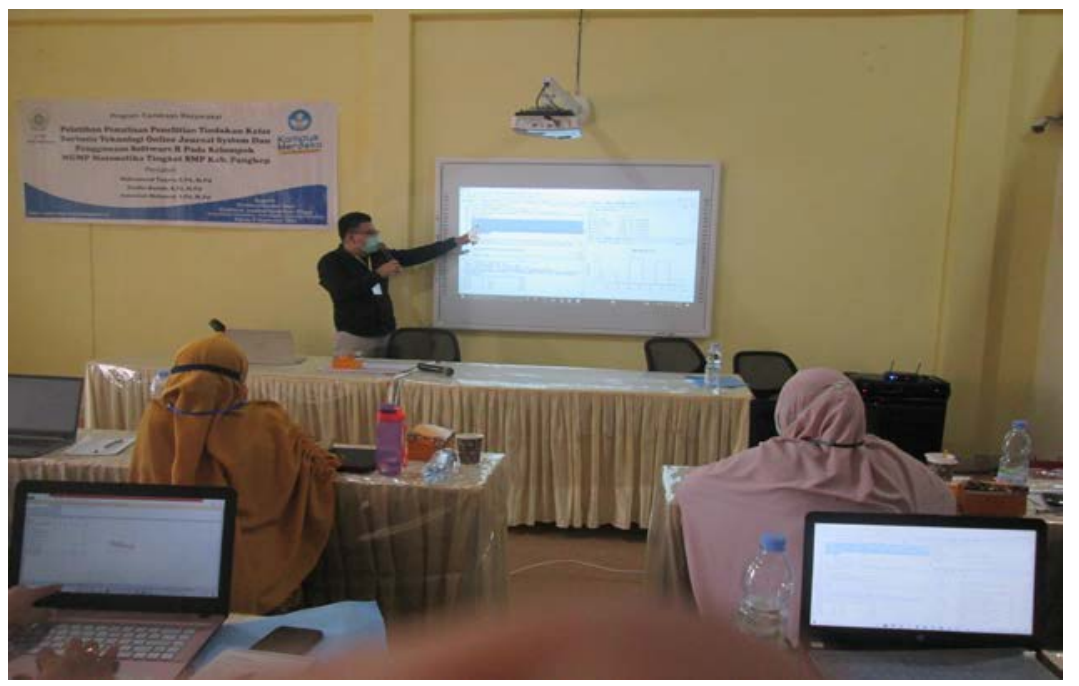

Gambar 3. Penyajian Materi PTK oleh Muhammad Taqwa, S.Pd, M.Pd.

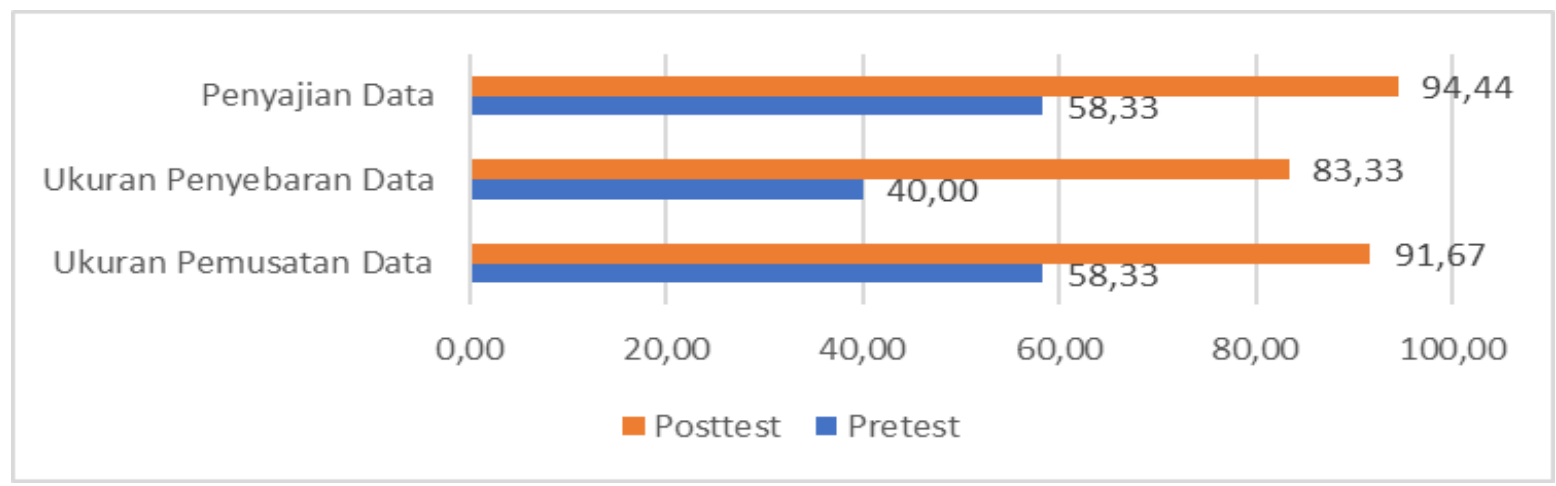

Gambar 4. Pengetahuan guru tentang mengolah data penelitian tindakan kelas dengan Software $R$

Grafik pada Gambar 4 menunjukkan bahwa adanya peningkatan pengetahuan guru tentang aplikasi statistika software $\mathrm{R}$ ditinjau dari indikator pengetahuan analisis data ukuran pemusatan penelitian tindakan kelas dengan software $R$, analisis data ukuran penyebaran penelitian tindakan kelas dengan software $R$, dan penyajian data penelitian tindakan kelas dengan software R. Setelah diberikan pelatihan kepada mitra mengenai pengolahan data hasil penelitian melalui software $\mathrm{R}$ telah dapat mengatasi permasalahan kesulitan mengolah dan menganalisis data hasil penelitian menggunakan software baik berkelompok/klasikal dan individual.

Pengetahuan Guru Tentang Publikasi Artikel Ilmiah Penelitian Tindakan Kelas Pada Open Journal System 


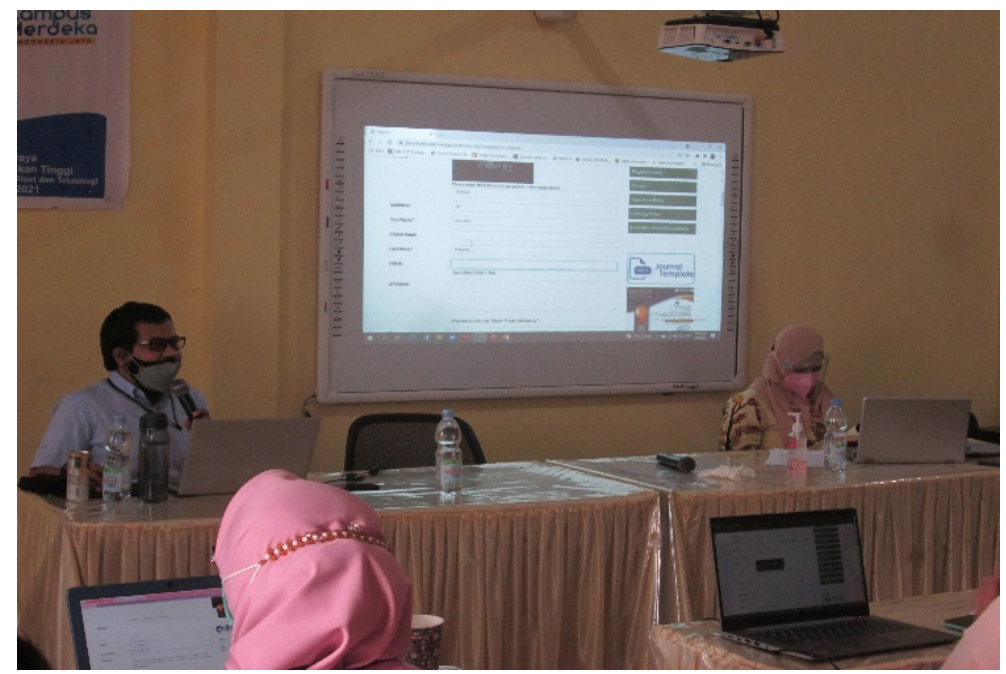

Gambar 5. Penyajian Materi PTK oleh Amrullah Mahmud, S.Pd., M.Pd.

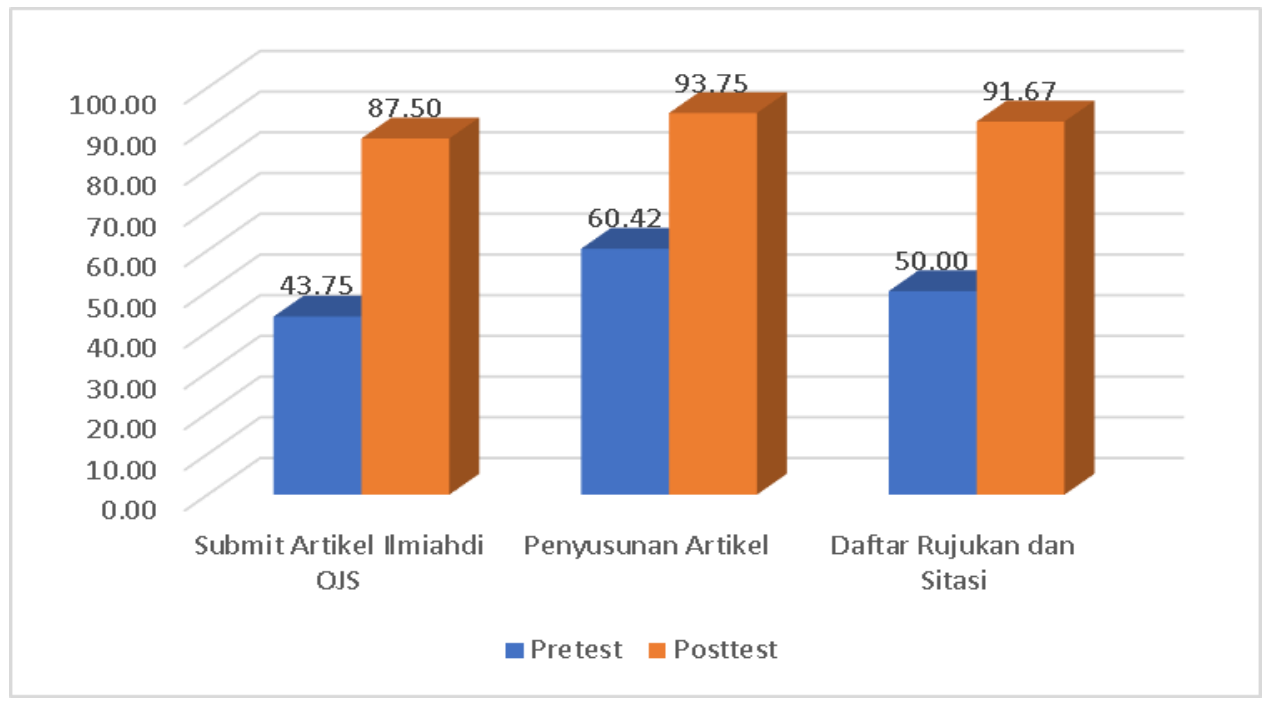

Gambar 6. Pengetahuan guru tentang publikasi artikel ilmiah penelitian tindakan kelas pada Open Journal System

Grafik pada Gambar 6 menunjukkan bahwa adanya peningkatan pengetahuan guru terkait OJS dengan indikator submit artikel ilmiah di OJS, penyusunan artikel, dan daftar rujukan dan sitasi. Peningkatan pengetahuan guru terkait OJS terbukti dengan tersubmitnya artikel ilmiah PTK yang disusun oleh mitra sebanyak 10 artikel di Jurnal Histogram. Setelah diberikan pelatihan. kepada mitra submit artikel ilmiah di OJS telah dapat mengatasi permasalahan kesulitan publikasi artikel ilmiah penelitian tindakan kelas di jurnal online baik berkelompok/klasikal dan individual.

\section{PEMBAHASAN}

Peningkatan pengetahuan guru terhadap cara penulisan penelitian tindakan kelas. Hasil pengabdian ini sesuai dengan kegiatan pengabdian. Hal ini dapat dilakukan karena didukung oleh hasil pengabdian Alimuddin \& Razak, (2016) ; Hasyim et al., (2017) ; Syafiq \& Rahmawati, (2018); Junaid et al., (2020) yang menunjukkan peningkatan kesadaran akan teknik penelitian, penerapan metodologi penelitian dalam menulis PTK, pengetahuan yang lebih besar tentang 
relevansi budaya ilmiah bagi mitra peningkatan menulis PTK oleh guru diduga faktor minat, kepercayaan diri, dan kompetensi guru (Fitria et al., 2019). Guru terhadap cara penulisan penelitian tindakan kelas memiliki hubungan dengan pengetahuan guru tentang publikasi artikel ilmiah. Hal ini didukung oleh hasil pengabdian (Oktoviana et al., 2020), yang menyimpulkan bahwa guru matematika yang dapat menulis ulang laporan penelitian tindakan kelas, maka mereka juga dapat menulis artikel ilmiah yang baik.

Peningkatan pengetahuan guru tentang mengolah data penelitian tindakan kelas dengan software R. Temuan ini sejalan dengan hasil pengabdian (Hasyim et al., 2017; Rosida et al., 2021), kegiatan pendampingan tentang teknik analisis data dapat meningkatkan pengetahuan dan keterampilan menggunakan software R. Diperkuat oleh hasil pengabdian (Rahayu \& Rohimah, 2019). Terbukti dengan tanggapan peserta dalam penelitiannya yang mengatakan 100 persen akan memanfaatkan Software $R$ untuk belajar atau meneliti. Peserta pelatihan juga mengatakan dengan tegas bahwa pelatihan perangkat lunak $\mathrm{R}$ benar-benar berguna bagi mereka. Dimensi orientasi tujuan intrinsik dan nilai tugas pada indikator motivasi pembelajaran diduga penyebab peningkatan pemahaman dan reaksi positif tersebut. Materi dalam modul menggunakan perangkat lunak $\mathrm{R}$ yang mendorong guru untuk mempelajari hal-hal baru berdasarkan fitur dimensi berorientasi tujuan intrinsic (Taqwa, 2020). Aspek nilai tugas, yang menyatakan bahwa faktor kemudahan saat menyelesaikan tugas, serta aspek nilai hadiah, dapat mempengaruhi motivasi belajar (Taqwa, 2017). Kemudahan itu disebabkan karena R merupakan software Statistika memiliki visualisasi grafik yang lebih canggih dan menarik dibandingkan software Statistika lainnya (Taqwa \& Taufik, 2019a, 2019b, 2019c). Selain itu, masih di aspek nilai tugas, karena sesuai dengan kebutuhan guru yaitu kesulitan dalam menganalisis data hasil penelitian Tindakan kelas untuk kebutuhan penyusunan PTK, maka guru merasakan materi pelatihan sangat bermanfaat untuk dipelajari (Taqwa, 2020). Peningkatan pengetahuan guru tentang mengolah data penelitian tindakan kelas dengan software $\mathrm{R}$ memiliki dampak dan keterkaitan dengan pengetahuan guru terhadap cara penulisan penelitian tindakan kelas. Hal ini dikarenakan analisis data (mengolah data) merupakan salah satu prosedur atau tahapan penulisan penelitian tindakan kelas (Astutik, 2019). Hal ini diperkuat oleh hasil pengabdian (Sumarjaya et al., 2014), yang menyimpulkan bahwa pelatihan dapat meningkatkan kemampuan guru dalam penggunaan software $\mathrm{R}$ dalam analisis data penelitian tindakan kelas secara tepat dan benar.

Peningkatan pengetahuan guru tentang publikasi artikel ilmiah penelitian tindakan kelas pada online journal system. Hal ini dapat dilakukan karena didukung oleh hasil pengabdian (Hadiyati \& Fatkhurahman, 2017) menjelaskan pengetahuan dan pemahaman tentang jurnal online dan jurnal cetak oleh guru telah berubah, mengubah pemahaman guru tentang menemukan OJS yang relevan dengan bidang artikel yang disusun, dan meningkatkan kemampuan guru untuk submit artikel yang disusun ke OJS. Diperkuat oleh hasil pengabdian Junaid et al., (2020); Susanti et al., (2020); Taqwa et al., (2021), yang mengatakan bahwa pengetahuan guru terkait publikasi ilmiah, menulis artikel ilmiah, menyusun sumber/kutipan/sitasi, serta mensubmit hingga accepted telah meningkat. Secara tidak langsung, 
guru yang memiliki pengetahuan publikasi artikel ilmiah yang baik maka guru tersebut juga dapat menyusun laporan penelitian tindakan kelas (Oktoviana et al., 2020).

\section{KESIMPULAN}

Hasil kegiatan pengabdian berupa pelatihan menunjukkan: (1) peningkatan pengetahuan guru terhadap cara penulisan penelitian tindakan kelas; (2) peningkatan pengetahuan guru tentang mengolah data penelitian tindakan kelas dengan software R; (3) peningkatan pengetahuan guru tentang publikasi artikel ilmiah penelitian tindakan kelas pada online journal system. Adapun saran yaitu sebaiknya pelatihan seperti ini rutin dilaksanakan setiap tahun supaya membantu meningkatkan literasi guru-guru matematika tentang penyusunan, pengolahan data, serta publikasi artikel ilmiah dari penelitian tindakan kelas.

\section{UCAPAN TERIMA KASIH}

Tim PKM berterima kasih kepada Direktur Sumber Daya, Direktur Jenderal Pendidikan Tinggi, Riset, dan Teknologi. Kementerian Pendidikan, Kebudayaan, Riset, dan Teknologi atas subsidi pendanaan untuk membantu pelaksanaan program kemitraan masyarakat bagi guru-guru di MGMP Matematika Tingkat SMP Kabupaten Pangkep.

\section{DAFTAR PUSTAKA}

Alimuddin, H., \& Razak, F. (2016). IbM Pentingnya PTK bagi Guru.

Astutik, S. (2019, November). Pemanfaatan Metode Statistika di Kabupaten Banyuwangi Guna Peningkatan Kemampuan Riset Guru di Banyuwangi. Tebar Karya UB: Buletin Pengabdian Kepada Masyarakat Universitas Brawijaya, 1(3), 18-19.

Direktorat Jenderal Pendidikan Anak Usia Dini. (2021). Data Pokok Pendidikan Pendidikan Dasar dan Pendidikan Menengah.

Fitria, H., Kristiawan, M., \& Rahmat, N. (2019). Upaya Meningkatkan Kompetensi Guru Melalui Pelatihan Penelitian Tindakan Kelas. Abdimas Unwahas, 4(1), 14-25. https://doi.org/10.31942/abd.v4i1.2690

Hadiyati, H., \& Fatkhurahman, F. (2017). Pelatihan Register Jurnal Ilmiah Ke Penerbit Open Journal System (OJS) pada Tenaga Pendidik di SMP N 4 Siak Hulu Kabupaten Kamp. Jurnal Diklat Review, 1(1), 12-17. https://doi.org/10.35446/diklatreview.v1i1.148

Hasyim, M., Ulum, W. M., \& Rahayu, D. S. (2017). Pelatihan Metodologi Penelitian Dan Pendampingan Penguasaan Aplikasi Statistika Software Open Source R dan SPSS Bagi Guru SMA. Seminar Nasional Hasil Pengabdian Kepada Masyarakat (SENIAS), 182-186.

Junaid, R., Baharuddin, M. R., \& Ramadhana, M. A. (2020). Bimbingan Teknis Penulisan Artikel Ilmiah bagi Guru-Guru SMP Negeri 8 Palopo Sulawesi Selatan. Abdimas Siliwangi, 3(2), 329-337.

Nur, M., \& Nasir, M. (2018). Program Kemitraan Masyarakat (PKM) Musyawarah Guru Mata Pelajaran (MGMP) IPA SMP untuk Mengembangkan Perangkat Pembelajaran Berbasis Potensi Lokal di Kabupaten Wajo. Jurnal Paradharma, 2(2), 103-108.

Nur, M., \& Nasir, M. (2019). PKM Musyawarah Guru Mata Pelajaran (MGMP) IPA Terpadu di Kabupaten Wajo untuk Penerapan Model-Model Pembelajaran Kurikulum 2013 Revisi 2017. Jurnal Pengabdian 
Kepada Masyarakat Sosiosaintifik (JurDikMas), 1(1), 1-8.

Oktoviana, L. T., Hasanah, D., Sulandra, I. M., Susiswo, Lestari, T. E., \& Nurhakiki, R. (2020). Pendampingan Penulisan Artikel Ilmiah dari Hasil Penelitian bagi Guru Matematika SMK Kota Kediri. ABDIMAS: Jurnal Pengabdian Masyarakat Universitas Merdeka Malang, 5(2), 115-122.

Pursitasari, I. D. (2014). Identifikasi Pengalaman Guru Ilmu Pengetahuan Alam dalam Penelitian Tindakan Kelas dan Penulisan Artikel Ilmiah. Seminar Nasional IPA V, 325-330.

Rahayu, W., \& Rohimah, S. R. (2019). Meningkatkan Keterampilanmenggunakan Software R Sebagai Solusi Untuk Meningkatkan Inovasi Pembelajaran Bagi Guru-Guru Matematika SMA DAN SMK di Jakarta Timur. Jurnal Sarwita, 12(2), 134-140.

Rosida, V., Taqwa, M., \& Kamaruddin, R. (2021). Pelatihan Pengolahan Data Melalui Program R Bagi Mahasiswa. MATAPPA: Jurnal Pengabdian Kepada Masyarakat, 4(1), 155-161.

Sugiono. (2018). Metode Penelitian \& Pengembangan (Research and Development). Alfabeta.

Sumarjaya, I. W., Ramona, Y., Rupiasih, N. N., Sibarani, J., Joni, M., \& Widagda, I. G. A. (2014). Pelatihan Metode Statistika Dalam Penelitian Tindakan Kelas Di SMPN 2 Kuta.

Susanti, E., Scristia, Aisyah, N., Hiltrimartin, C., Hartono, Y., Somakim, Meryansumayeka, Araiku, J., Pratiwi, W. D., Kurniadi, E., \& Saputri, N. W. (2020). Pendampingan Penulisan Artikel Ilmiah Penelitian Tindakan Kelas bagi Guru Matematika. Jurnal Anugerah, 2(2), 93-100.

Syafiq, A. N., \& Rahmawati, A. (2018). PKM Peningkatan Penguasaan PTK pada Guru-Guru di Sekolah Dasar di Desa Kutuk Undaan Kudus. Abdimas, 1(1), 9-11.

Taqwa, M. (2021). Metode Suksesif Interval Pada Motivasi Belajar Matematika Selama Covid-19 Berbasis MSLQ Dengan Software R. Seminar Nasional Pendidikan Matematika (SANDIKA 2), 29-40.

Taqwa, M. (2017). Pengaruh Pendekatan Pembelajaran Dan Bentuk Tes Formatif Terhadap Prestasi Dan Motivasi Belajar Matematika. Seminar Nasional Matematika IndoMS Wilayah Sulawesi SENAMAS, 300312.

Taqwa, M. (2020). Pengembangan lembar kerja mahasiswa (LKM) untuk menumbuhkan motivasi belajar pada matakuliah kalkulus lanjut di masa pandemi Covid-19. Seminar Nasional Matematika Dan Pendidikan Matematika (5th SENATIK), 263-275.

Taqwa, M., Kamaruddin, R., \& Rosida, V. (2021). Pelatihan Penyusunan dan Teknik Pengusulan Proposal Program Kreativitas Mahasiswa pada Mahasiswa. MATAPPA: Jurnal Pengabdian Kepada Masyarakat, $4(1), 135-141$.

Taqwa, M., \& Taufik, A. (2019a). Pengembangan Buku Ajar Statistika Dengan Software R Untuk Meningkatkan Motivasi Belajar Dan Pemahaman. Histogram: Jurnal Pendidikan Matematika, 3(2), 122 140.

Taqwa, M., \& Taufik, A. (2019b). Statistika dengan R. Deepublish.

Taqwa, M., \& Taufik, A. (2019c). Pengembangan Buku Statistika dengan Software R untuk Meningkatkan Motivasi Belajar dan Pemahaman. Seminar Nasional FKIP Universitas Muslim Maros, 81-87. 